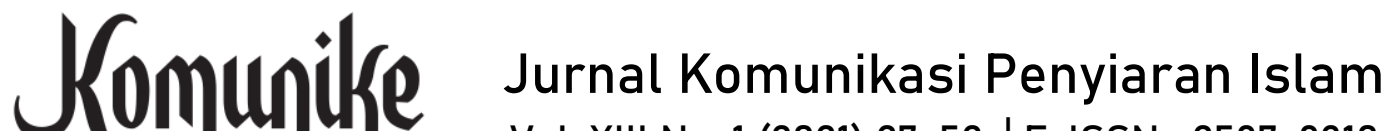 \\ Vol. XIII No. 1 (2021) 27-52 | E-ISSN : 2597-9310
}

Submission : $24-02-2021$

Revision : $15-06-2021$

Published : $25-06-2021$

\section{KOMUNIKASI SPIRITUAL DALAM TRADISI SEDEKAH SERABI DI EMPAT LAWANG, SUMATERA SELATAN}

\author{
Pipin Yosepin \\ STAI Al Aqidah Al Hasyimiyyah, Jakarta \\ pipin.nurjannah@gmail.com
}

\begin{abstract}
This article describes the socio-religious study of the existence of Islam and the local culture of the serabi alms tradition in Empat Lawang, South Sumatra. This research was studied through a phenomenological approach. In the tradition of sadaqah serabi, spiritual communication is established between the jurai tuo and the ancestors to form belief in the Creator. Exploration of the original belief in the Empat Lawang community indicates that there is a collective awareness that the intentions that are owned are mediated in the power of prayers from the ancestors through expressions of gratitude and vows that have been granted. Serabi charity proves that local culture has not changed after the entry of Islam. As a religion, Islam has empirically influenced, and even been accepted peacefully, to form the structure of the dimensions of human life in a socially and culturally dynamic manner.
\end{abstract}

Keywords: Islamic Interaction, Serabi Alms, Spiritual Communication

\begin{abstract}
Abstrak
Artikel ini menjelaskan tentang studi sosio religius terhadap eksistensi Islam dan budaya local tradisi sedekah serabi di Empat Lawang, Sumatera Selatan. Penelitian ini dikaji melalui pendekatan fenomenologi. Dalam tradisi sedekah serabi terjalin komunikasi spiritual antara jurai tuo dan leluhur sehingga membentuk keyakinan pada Sang Pencipta. Eksplorasi terhadap kepercayaan asal pada masyarakat Empat Lawang mengisyaratkan adanya kesadaran kolektif bahwa niat yang dimiliki dimediasikan dalam kekuatan doa dari leluhur melalui ekspresi rasa syukur dan nazar yang telah dikabulkan. Sedekah serabi membuktikan bahwa budaya 27ocal tidak berubah setelah masuknya Islam. Sebagai agama, Islam secara empirik telah ikut mempengaruhi, bahkan diterima secara damai membentuk struktur dimensi kehidupan manusia secara sosial dan budaya yang dinamis.
\end{abstract}

Kata Kunci : Interaksi Islam, Sedekah Serabi, Komunikasi Spiritual 
Komunike, Volume XIII, No. 1 Juni 2021

\section{A. PENDAHULUAN}

Keberadaan Islam di Indonesia, khususnya di Sumatera Sealatan dalam jejak historis telah banyak mendapat perhatian dari sejarawan dan berbagai ilmuwan juga budayawan. Banyaknya pendapat yang mengatakan persoalan tersebut menjelaskan bahwa tema Islam memang menarik untuk dikaji, terlebih karena negeri kita memiliki mayoritas penduduk muslim. Dengan demikian eksistensi Islam mendapat tempat dan mampu mengikat begitu banyak pengikut di Nusantara serta cukup punya nilai dalam memahami dan memaknai lebih dalam dinamika eksistensi keberagamaan Islam di Indonesia.

Masuknya dan berkembangnya agama Islam di kabupaten Empat Lawang merupakan bagian dari integral dari kedatangan dan penyebaran agama Islam di daerah Palembang, Sumatera Selatan khususnya dan di Indonesia pada umumnya. ${ }^{1}$ Dalam penyebaran agama Islam terutama dalam lingkup kota Palembang, dapat dilihat sejak kondisi Islam pada abad ke-17 M hingga abad ke-20 M merupakan fase perkembangan Islam di Palembang secara umum, hal ini ditandai dengan Islam sebagai "agama resmi" yang dipelihara oleh struktur kekuasaan pada masa kesultanan Palembang Darusalam, dimana eksistensi Islam tampak pada peranan birokrat agama yang tidak terdapat pada tingkat pusat kerajaan

1 Pipin Yosepin, Masuknya Islam ke Empat Lawang, dalam Presentasi Makalah Seminar ICMI : Masuknya Islam ke Empat Lawang, Empat Lawang Desember 2020 namun hal itu berlaku juga di tingkat marga dan pesirah di pedalaman/uluan. ${ }^{2}$

Menurut Ma'moen Abdullah, Sultan Abdurrahman dan keturunanketuruannnya giat menyebarkan Islam ke daerah uluan, bahkan memberikan kebebasan kepada setiap pedagang yang akan menyebarkan agama sambil berdagang hingga jauh menyebar ke Empat Lawang. ${ }^{3}$ Dari jejak seajrah disebutkan bahwa agama Islam berkembang secara pesat di masa kesultanan Palembang Darusalam pada masa pemerintahan Kayi Mas Endi, Pangeran Ario Kesuma Abdurrohim, Sultan Susuhunan Abdurrohman, Khalifatul Mukminin Sayidul Imam (1659-1706). Para pemimpin awal ketika Palembang sudah lahir mempunyai ketertarikan yang lebih terhadap agama. Hal tersebut tercermin pada apa yang mereka lakukan dan usahakan dengan cara menarik para ulama Arab agar sekali lagi menetap di wilayah mereka. ${ }^{4}$

Islam merupakan agama yang berisi ajaran-ajaran dari wahyu yang diturunkan oleh Allah kepada RasulNya untuk disampaikan kepada segenap umat manusia sepanjang masa. Islam merupakan agama yang didalamnya mengatur sistem kehidupan umat manusia baik akidah dan akhlak dan terdapat hubungan baik manusia dengan Tuhannya maupun hubungan manusia dengan sesama manusia

\footnotetext{
2 Dedi Irwanto dan Muhammad Santun, Venesia dari Timur Memaknai Produksi dan Reproduksi Simbolik Kota Palembang dari Kolonial sampai pascakolonial, (Ombak, 2011),h. 1.

${ }^{3}$ Ibid, h. 213.

${ }^{4}$ Ibid, h. 213.
} 
ataupun hubungan manusia dengan alam, yang bertujuan mengharapkan keridhaan Allah serta rahmat bagi sekalian alam kebahagiaan di dunia dan di akhirat. (Anshari, 1993:19) Islam yang berasal dari kata "salima" menjadi "yaslaamu”, "salaaman" dan salaamatan" yang berarti damai, penuh kebaikan, keseimbangan, toleransi, sabar dan menahan marah. ${ }^{5}$ Dalam AlQuran dijelaskan bahwa Islam secara esensia; merujuk pada pengertian damai, perlindungan , keamanan dan kenyaman. ${ }^{6}$ Luthfi dalam pendapatnya menyebutkan bahwa Islam disebut juga agama rahmatan lil alamin artinya membawa rahmat bagi seluruh alam yang melewati tetap tetap suku bangsa tradisi, bahasa dan warna kulit, yang hal ini merupakan symbol universalisme Islam yang menjadi sumber kekuatan dan keistimewaan agama Islam. ${ }^{7}$

Agama menjadi pedoman hidup manusia, diciptakan oleh Tuhan dalam menjalani kehidupan. Sedangkan kebudayaan adalah sebagai kebiasaan, tata cara hidup manusia diciptakan oleh manusia itu sendiri dari hasil daya cipta rasa dan karsa yang diberikan oleh Tuhan. Agama dan kebudayaan sifatnya saling mempengaruhi satu sama lain. Agama mempengaruhi kebudayaan kelompok masyarakat yang suku bangsa kebudayaannya cenderung berubahubah dan berimplikasi pada keasrian

5 Ismail Yahya, Islam Rahmatan Lil Alamin, Artikel, 13 Juli 2018.

${ }^{6}$ Muhammad Tahir-Ul-Qadri, Fatwa Tentang Teorisme dan Bom Bunuh Diri, (Jakarta:LPPI,2014).

${ }^{7}$ Khabibi Muhammad Luthfi, Islam Nusantara Relasi Islam dan Budaya Lokal, dalam Jurnal SHAHIH, Vol.1 No.1, januari- Juni 2016,h.2. agama, sehingga menghasilkan penafsiran berlainan. Salah satu agenda besar dalam kehidupan masyarakat berbangsa dan bernegara adalah menjaga persatuan dan kesatuan dan membangun kesejahteraan bersama seluruh warga negara umat beragama.

Fenomena kehidupan masyarakat Indonesia dilihat dari aspek agama dan budaya yang memiliki keterkaitan satu sama lain terkadang banyak disalah artikan oleh sebagian orang yang belum memahami bagaimana menempatkan posisi agama dan posisi budaya dalam suatu kehidupan. Bauto (dalam pendapatnya mengatakan masyarakat dalam kehidupan manusia agama dan budaya jelas tidak berdiri sendiri Keduanya memiliki hubungan yang sangat erat dalam dialektikanya selaras menciptakan, kemudian saling menegasikan. ${ }^{8}$ Persoalan ini semakin krusial ketika terdapat rangkaian kondisi sosial yang menimbulkan konflik di masyarakat sehingga terganggu kebersamaan dalam membangun keadaan yang lebih dinamis dan kondusif kebanggaan terhadap kerukunan dihasilkan selama bertahun-tahun mengalami degradasi bahkan di bukan kecemasan terjadinya disintegrasi bangsa.

Islam sebagai agama yang lahir ke dunia merupakan salah satu usaha manusia untuk mendekatkan diri pada kekuatan supranatural yang

${ }^{8}$ Laude Mondo Bauto, Perspektif Agama dan Kebudayaan dalam Kehidupan Masyarakat Indonesia suatu Tinjauan Sosiologi Agama, dalam JPS Jurnal Pendidikan Ilmu Sosial, Vol. 23 No. 2, edisi Desember 2014, h. 24. 
menganggap masalah adanya kekuatan yang dianggap lebih tinggi dari kekuatan yang ada pada dirinya, sehingga manusia mencari lebih dalam dari mana asal kekuatan yang ada pada alam, baik berupa gunung, laut, langit dan sebagainya. Ketika mereka tidak dapat mengkajinya maka disembah karena mereka berpikir bahwa kekuatan itu memiliki kekuatan yang luar biasa dan bisa menghidupi beribu-ribu bahkan berjuta-juta umat manusia.

Penelitian ini didasarkan pada asumsi bahwa Islam sebagai agama universal $^{9}$ berlaku disegala tempat dan zaman. (shalihun likuli makan wa zaman) dan membawa rahmat bagi semesta alam. (rahmatan lil alamin). Hal ini dapat diyakini bahwa Islam sebagai agama yang membawa berbagai konsekuensi antara lain agama Islam yang bisa dianut oleh berbagai bangsa dan masyarakat dengan latar belakang, etnis dan budaya yang berbeda-beda.

Sejak dahulu sebelum Islam datang, masyarakat Nusantara sudah memiliki keyakinan pada sang pencipta. Agama asal yan disebut dengan animisme dan dinamisme pada suku-suku yang ada di pedalaman Nusantara, termasuk sukusuku di Empat Lawang, Sumatera Selatan, sejak dulu telah mengakar dalam. Warisan dan tradisi budaya dalam kepercayaan menjadi bentuk kebudayaan lokal dan diekspresikan dalam tradisi lokal. Agama Islam yang

\footnotetext{
9 Lajnah Pentatashihhan Mushaf Al Qur'an Badan Litbang Dan Diklat Kementrian Agama RI, Tafsir Al-Qur'an dan Tematik, Sinergitas Internal Umat Islam, Jakarta: Lajnah Petashihan Mushaf Al-Qur'an, 2017, h.66.
}

kemudian datang dan menyebar pada daerah-daerah yang umumnya telah memiliki tradisi atau adat istiadat berakar dan diwarisi secara turun temurun dari nenek moyang tersebut menunjukkan bahwa Islam dalam realitasnya mampu menampakkan kearifannya dengan ditandai pendekatan dakwah secara damai dan bertahap atau pelan-pelan, bukan dengan cara yang keras dan radikal.

Dengan kata lain keberadaan Islam mampu berdialektika ${ }^{10}$ secara harmonis dengan kemajemukan adat budaya dan memberikan klarifikasi secara bijaksana terhadap unsur adat di daerah tersebut. Nilai positif dari budaya lokal dapat dipelihara dan unsur adat yag dianggap dengan nilai negatif mulai ditinggalkan. Dengan demikian, Islam datang bukan untuk menghancurkan adat atau menghilangkan budaya setempat, namun untuk memperbaiki dan meluruskannya menjadi lebih berperadaban dan manusiawi. ${ }^{11}$

Saat ini masih sering kita saksikan sebagian anggota masyarakat mencampuradukkan antara nilai agama dan nilai budaya yang keduanya tentu saja tidak $100 \%$ sama kan bahkan mungkin berlawanan. Namun demi terjaganya eksistensi dan kesucian nilainilai agama sekaligus memberi pengertian maka dalam hal ini eksistensi Islam sebagai agama menurut penulis perlu dikuatkan dengan

10 Rohimin dan Zubaidi, et.all., Penyerapan Nilai-Nilai Budaya Lokal Dalam Kehidupan Beragama di Bengkulu (Studi Tentang Tradisi Tabot di Bengkulu), ( Jakarta: Balai Penelitian dan Pengembangan Agama Jakarta, 2009), h. 4. ${ }^{11}$ Ibid, h. 4. 
hubungan yang kuat dengan budayabudaya yang kita sebut dengan merupakan warisan dari nenek moyang sampai saat ini.

Eksistensi Islam di Sumatera Selatan, khususnya di Empat Lawang berasal dari para pedagang-pedagang yang berasal dari Arab yang datang sejak abad ke-7. Berlangsungnya proses Isalmisasi tersebut membuat agama dakwah yang disebarkan tersebut tersebar dari Palembang hingga ke wilayah pedalaman/uluan Sumatera Selatan sejak abad ke-14. Masyarakat Palembang termasuk ke wilayah Empat Lawang dan sekitarnya, kemudian menjadi sasaran dakwah oleh para pedagang ini untuk menyebarkan misi dakwahnya. ${ }^{12}$

Dari geografis Palembang pengaruh sungai Musi yang melintasi daerah pedalaman/uluan menunjukkan akulturasi dalam penyebaran budaya dan pengaruh Islam Palembang. Banyaknya ragam tradisi dari multi suku (etnis) yang dipengaruhi lintasan sungai Musi, Batang hari Sembilan sehingga ada sekitar 12 suku atau marga yang berpengaruh terhadap dialek bahasa lokal, sistem kepuyangan dan ragam adat/tradisi. ${ }^{13}$ (Farida, 2019:54). Agama Islam yang dipeluk oleh penduduk Palembang tersebut telah mewarnai perkembangan peradaban tersendiri di wilayah ini. Penyebaran Islam tersebut berpengaruh terhadap

12 Ida Farida dan Endang Rochmiatun, dkk, Peradaban Islam Palembang, JUSPI, Jurnal Sejarah Peradaban Islam), No. 3 Vol. 1, 2019, h.54.

${ }^{13}$ Ibid, h.54. corak dan varian yang dimiliki Islam Palembang. Proses dialektika tersebut pada gilirannya menghasilkan Islam Palembang yang unik, khas, dan esoterik dengan ragamnya tradisi-tradisi yang sudah disisipi nilai-nilai Islam.

Oleh karena itu penting bagi peneliti untuk mengkaji lebih dalam terkait budaya lokal sedekah serabi yang sebelum Islam sudah dilakukan di masyarakat Empat Lawang, Sumatera Selatan. Dan saat ini pemerintah Kabupaten Empat Lawang mulai melestarikan tradisi sedekah serabi sebagai kearifan lokal masyarakat Empat Lawang untuk menjadi warisan tak benda PBB. ${ }^{14}$

\section{B. LITERATURE REVIEW}

Penelitian yang pernah dikaji berkaitan dengan Islam dan budaya lokal, diantaranya yaitu: Pertama, Sabara $^{15}$ Peneliti Balai Litbang Makasar, dengan judul Islam dan Tradisi Masyarakat Lokal di Sulawesi Selatan (Sulsel)." Penelitian berfokus tentang tradisi, proses Islamisasi pada masyarakat Sulsel hingga proses integrasi Islam dengan budaya lokal Sulsel. dalam penelitian ini kehadiran Islam memberikan warna pada pelaksanaan adat istiadat dan berbagai tradisi dalam masyarakat Sulsel. Menurut penulis, penelitian ini tidak membahas dalam tentang tradisi lokal di Sulsel namun lebih pada proses islamisasi di Sulsel yang memberi warna budaya lokal sehingga terbentuk

\footnotetext{
14 Vebri al Lintani, Wawancara, 20 September 2019 di Empat Lawang.

15 Sabara, Islam dan Tradisi Masyarakat Lokal di Sulawesi Selatan (Sulsel).”, 2018.
} 
kebudayaan baru yang diisi dengan warna Islam. Terjadinya akulturasi budaya di Sulsel menunjukkan bahwa Islam datang lentur, tidak memaksakan ajarannya. Perjumpaan Islam dan budaya lokal di Sulses menghadirkann tiga model yaitu integrasi, negoisasi bahkan negasi.

Kedua, Muhaimin $\mathrm{AG}^{16}$ dalam Islam dan Budaya Lokal dalam Potret Islam Cirebon (Disertasi), Masalah yang diangkat dalam penelitian ini yaitu tentang potret masyarakat Cirebon dalam kehidupan sehari-hari. Dalam hal ini dipotret secara global baik dari sisi kepercayaan dan cara praktiknya, mitologi, kosmologi tradisi Cirebon. Penelitian ini menunjukkan bahwa adanya sinkretisme Jawa yang masih melekat kental pada masyarakat Cirebon. Hakekat dan dinamika Islam Jawa di Cirebon tergambar dengan jelas praktik keagamaan masyarakat Cirebon. Menurut penulis penelitian ini menjadi rujukan dan referensi dalam menganalisa praktik keberagamaan Islam lokal dan budaya lokal.

Ketiga, Clifford Geertz , dalam karyanya yang terkenal dengan "The Religion of Java"17, diterjemahkan menjadi "Agama Jawa: Abangan, Santri dan Priyayi dalam Kebudayaan Jawa". ${ }^{18}$ Dalam penelitiannya Geertz menjelaskan bahwa tradisi selametan merupakan pusat sistem keagamaan

\footnotetext{
${ }^{16}$ Muhaimin AG, , Islam daam Bingkai Budaya Lokal Potert Dari Cirebon, Ciputat: PT Logos Wacana Ilmu, 2002.

17 Clifford Geertz, Agama Jawa: Santri, Abangan dan Priyayi Dalam Kebudayaan Jawa, Depok: Komunitas Bambu, 2013.

${ }^{18}$ Geertz, Agama Jawa,....., 2013.
}

orang Jawa. Geertz mengkonstruksi corak perlaku keagamaan masyarakat Jawa (desa Mojokuto), upacara keagamaan yang kental dengan kekudusan dan skaral sampai mistis juga kesenian di amati Geertz sebagai usaha peneguhan ikatan masyarakat Jawa. Geertz menguraikan golongangolongan dalam masyarakat Jawa yang pertama disebut "abangan" yaitu golongan yang memiliki struktur kehidupan sosial dan orientasi serta perilaku yang memancarkan hubungan keagamaan dari kelompok sosial dan orientasi serta perlaku yang memancarkan hubungan keagamaan dari kelompok sosial yang memantulkan suasana dan tata kehidupan pedesaan. Ada kecenderungan animistis pada golongan ini terutama pada tradisi selametan. Golongan kedua disebut golongan santri yang menguasai pasar dan taat pada ajaran Islam, berpuasa, sholat. Golongan sosial tersebut menghasilkan kelompok-kelompok keagamaan seperti Nadhlatul Ulama, (NU) dan Muhammadiyah. Golongan ketiga disebut Geertz sebagai golongan priyayi yang memiliki kecenderungan Hinduistis yang bermuara di keraton. Kondisi status soail di keraton lebih kepada ajaran dan praktik kebatinan. Dalam hal ini Geertz menelusuri seluk beluk dan kedalaman kehidupan spiritual jawa serta masalah integrasi politik dan sosial yang dicerminkan dalam agama. Penulis menjadikan penelitian Geertz rujukan dalam memahami dan manganalisis praktik tradisi sedekah serabi dan karakteristik pemahaman keagamaan pada masyarakat di desa Gunung Merakso 
dan desa Perigi, Empat Lawang karena ada kesamaan dalam tradisi sedekah serabi dan selametan serta munculnya kelompok ideologi keagamaan yang berpengaruh terhadap tumbuh kembangnya sedekah serabi di Empat Lawang.

\section{Teori Agama dan Kebudayaan}

Agama dan budaya merupakan dua sisi yang saling berhubungan erat dan memiliki hubungan timbal balik. Agama memberikan kontribusi terhadap nilai-nilai budaya, sehingga agama bisa berdampingan atau bahkan berasimillasi dan melakukan akomodasi dengan nilainilai budaya masyarakat. Menurut Anne Marie Malefitjt ${ }^{19}$, dikatakan bahwa agama merupakan the most important aspect of culture. Aspek kehidupan beragama tidak hanya ditemukan dalam setiap masyarakat, tetapi juga berinteraksi dengan institusi budaya yang lain dalam struktur masyarakat. Dalam pernyataan Malefitjt tersebut agama merwarnai kebudayaan.

Namun pada sisi lain agama sebagai wahyu dan memiliki kebenaran mutlak (terutama agam samawi) dan universal, maka agama tidak dapat disejajarkan dengan nilai-nilai budaya yang relatif dan lokal. Agama harus menjadi sumber nilai bagi kelangsungan nilai-nilai suatu budaya. Yang menjadi masalah adalah apakah nilai-nilai agama atau nilai-nilai budaya lebih dominan dalam kehidupan masyarakat tersebut. ${ }^{20}$ Sedangkan lokalitas adalah sesuatu yang bersifat lokal, "indigenous" (pribumi) atau budaya pada suatu

\footnotetext{
${ }^{19}$ Agus, 2006, h.5.

${ }^{20}$ Wahyuni, 2013,h.14.
}

masyarakat lokal, yang meliputi ilmu pengetahuan, kepercayaan,kesenian, moral, hukum, adat dan kemampuan serta kebiasaan lainnya, yang didapatkan manusia sebagai anggota masyarakat. ${ }^{21}$ Agama dan kebudayaan mempunyai dua persamaan yaitu keduanya adalah sistem nilai dan sistem simbol yang diresapi, dihayati, diyakini serta diejawantahkan dalam praksis laku hidup manusia. Agama dalam perspektif ilmu-ilmu sosial adalah sebuah sistem nilai yang memuat sejumlah konsepsi menenai kostruksi realitas yang berperan besar dalam menjelaskan struktur tata normatif dan tata sosial serta menanamkan dan menafsirkan dunia sekitar. Sementara tradisi merupakan ekspresi cipta, karya dan karsa manusia (dalam masyarakat tertentu) yang berisi nilai-nilai dan pesan-pesan religiusitas, wawasan filosofis dan kearifan lokal (local wisdom). Agama dan ruang lingkupnya cenderung bersifat global,sedangkan kebudayaan atau tradisi ruang lingkupnya lebih lokal atau hanya menjadi milik komunitas tertentu yang hidup pada suatu batasan wilayah tertentu. $^{22}$

Clifford Geertz ${ }^{23}$ berpendapat bahwa agama kerap tumpang tindih dengan kebudayaan. Agama dan kebudayaan bertemu dalam ruang sosial dan salah sama lain menampilkan identitasnya masing-masing dengan segala kekhasannya maka agama

\footnotetext{
${ }^{21}$ Selp, 1991

${ }^{22}$ Sabara, "Islam Dalam Tradisi Masyarakat Lokal di Sulawesi Selatan", Jurnal Mimikiri, Vol. 4 No.1 2018, h.52.

${ }^{23}$ Agus, 2005, h.9.
} 
sebagai narasi universal dan global serta dengan klaim absolut kemudian merespon kebudayaan sebagai narasi lokal. Meski keduanya berbeda pada basis narasi, namun menempati posisi yang sama yaitu menempati ruang sakral dan profan dalam kehidupan manusia.

Agama juga sebagai sumber sosial normatif mendorong perilaku kolektif manusia karenanya agama dipandang sebagai salah satu bagian dari sistem sosial dan sistem budaya suatu masyarakat. Agama punya kaitan erat dengan ekonomi, sosial, politik, hukum, dan kebudayaan. Sehingga dpat dipahami pula sebagai substansi nilai yang erat kaitannya dengan aspek pengalaman yang mentransedentalkan sejunlah eksistensi sehari-hari dengan melibatkan kepercayaan dan tanggapan pada sesuatu yang berada di luar jangkauan manusia. Agama dalam hal ini memiliki dua fungsi yaitu pertama, satu cakrawala pandang tentang hal-hal metafisis yang tidak terjangkau akal mansuia dan cara pandang atau gejalagejala alamiah pada makhluk bersifat determistik. Hubungan antara pengalaman supranatural manusia yang susah terbantahkan secara logika sangat logis untuk dikatakan tidak logis untuk dikatakan irasional. Kedua, agama sebagai sarana ritual memungkinkan hubungan manusia dengan keberadaan sesuatu atas keyakinannya. Eksistensi yang berada di luar jangkaunan akal diupayakan untuk dikomunikasikan dalam simbol-simbol tertentu sebagai perwujudan dialog antara hamba dengan Tuhan. ${ }^{24}$

Agama sebagai sistem religi membutuhkan perwujudan budaya dalam bentuk simbol atau tindakan simbolis yang merupakan relasi komunikasi antara human kosmis dengan komunikasi reigius yan bersifat lahir maupun batin. ${ }^{25}$ Dengan demikian keyakinan atas agama adalah kebudayaan terbesar dalam sejarah hidup manusia. Agama tidak dapat keluar dari jiwa manusia, simbol-simbol dalam beragama djadikan alat komunikasi dengan Tuhan, merupakan yang paling pertama lahir pada manusia. 26

Sebuah keunikan bangsa Indonesia karena memiliki keragaman etnis, budaya dan bahasa. Oleh karenanya Indonesia memiliki khazanah budaya dalam jumlah yang tersebar di nusantara. ${ }^{27}$ Budaya disebut culture artinya keseluruhan sistem gagasan dan tindakan.Menurut Robert Mitchel, kebudayaan merupakan segala sesuatu yang diperolah individu dari masyarakat mencakup kepercayaan, adat istiadat, norma, artitiska, kebiasaan dan keahlian yang diperoleh bukan dari kreativitasnya sendiri melainkan merupakan warisan masa lampau yang diperoleh melalui pendidikan formal dan infromal. ${ }^{28}$

\footnotetext{
${ }^{24}$ Zaenal Abidin Yusuf, 2013, h. 101-102.

25 Herusatoto, Budiono, Simbolisme Jawa, (Yogyakarta: Ombak, 2007), h. 45

${ }^{26}$ Zaenal Abidin,( 2013),h.102.

27 Achadiati Ikram, Pemeliharaan Sastra Lama Masyarakat Masa Kini, Beberapa Masalah Perkembangan Ilmu Filologi Dewasa Ini, (Jakarta: Diktat Kuliah Fakultas Sastra Universitas Indonesia, 1993. h.6-9.

${ }^{28}$ Zaenal Abidin Yusuf, 2013,h.39.
} 
Komunike, Volume XIII, No. 1 Juni 2021

Budaya merupakan warisan dari dari nenek moyang terdahulu yang masih eksis sampai saat ini. Suatu bangsa tidak akan memiliki ciri khas tersendiri tanpa adanya budaya-budaya yang dimiliki. Budaya-budaya itupun berkembang sesuai dengan kemajuan zaman yang semakin modern. Kebudayaan yang berkembang dalam suatu bangsa itu sendiri dinamakan dengan kebudayaan lokal, karena kebudayaan lokal sendiri merupakan sebuah hasil cipta, karsa dan rasa yang tumbuh dan berkembang di dalam suku bangsa yang ada di daerah tersebut. Menurut Judistira, kebudayaan lokal adalah segala bentuk kebudayaan daerah baik cara berperilaku, bertindak dan pola pikiran yang berada jauh di belakang apa yang tampak tersebut. ${ }^{29}$

Budaya lokal merupakan budaya yang dimiliki oleh masyarakat yang menempati lokalitas atau daerah tertentu yang berbeda dari budaya yang dimiliki oleh masyarakat yang berada di tempat yang lain. Permendagri Nomor 39 Tahun 2007 pasal 1 mendefinisikan budaya daerah sebagai "suatu sistem nilai yang dianut oleh komunitas/ kelompok masyarakat tertentu di daerah, yang diyakini akan dapat memenuhi harapan-harapan warga masyarakatnya dan di dalamnya terdapat nilai-nilai, sikap tata cara masyarakat yang diyakini dapat

29 Tuti Andriani, Revitaliasasi naskah Syair: Sebuah Solusi Dalam Pengembangan Kreativitas Mahasiswa Untuk Mencintai Budaya Lokal, Jurnal Sosial Budaya, Vol.11 Nomor. 1, 2014, dikutip dari K. Judistira K. Garna, Budaya Sunda: Melintasi Waktu Menantang Masa Depan. Bandung: Lemlit Unpad. 2008, h.41. memenuhi kehidupan warga masyarakatnya".30

Budaya-budaya lokal yang kemudian berakulturasi dengan Agama Islam antara lain, acara slametan $(3,7,40,100$, dan 1000 hari) di kalangan suku Jawa. Tingkeban (nujuh hari). Dalam bidang seni, juga dijumpai proses akulturasi seperti dalam kesenian wayang di Jawa. Wayang merupakan kesenian tradisional suku/etnis Jawa yang berasal dari agama Hindu India. Proses Islamisasi tidak menghapuskan kesenian ini melainkan justru memperkayanya, yaitu memberikan warna nilai-nilai Islam di dalamnya. Tidak hanya dalam bidang seni, tetapi juga di dalam bidang-bidang lain di dalam masyarakat Jawa. Dengan kata lain kedatangan Islam di Indonesia dalam taraf-taraf tertentu memberikan andil yang cukup besar dalam pengembangan budaya lokal.

Kabupaten Empat lawang, disebut bagian dari daerah uluan telah menjadi daerah yang penting bagi perkembangan kebudayaan di Sumatera Selatan. Hal ini karena salah satunya pengaruh dari kerajaan Sriwijaya yang luas. Palembang merupakan pusat dari kerajaan Sriwijaya. ${ }^{31}$ Kota Palembang ini menjadi penting untuk diteliti sebagai lokasi awal persebaran kebudayaan Melayu, yang kemudian meluas sampai ke daerah-daerah se-

\footnotetext{
${ }^{30}$ Setyawan Agung, Budaya Lokal Dalam Perspektif Agama: Legitimasi Hukum Adat ('Urf) Dalam Islam, Jurnal Esensi, Vol. XIII No. 2 Juli 2012, hlm.208.

31 W.P. Groenveldt, Historical Notes on Indonesia and Malaya, Compiled From Chinese Sources, Jakarta: Bhratara, 1960.
} 
Sumatera Selatan. Berdasarkan sumber sejarah Melayu, dalam cerita tutur Palembang, Babad tanah Jawi maupun dari sumber Barat oleh George Coedes, ${ }^{32}$ seorang sarjana Perancis pada tahun 1918 dalam bukunya Le Royaume de Crivijaya disebutkan kembali nama Sriwijaya setelah Sriwijaya runtuh. Hal ini meunjukkan bahwa Palembang memiliki keunikan tersendiri, karena pernah berjaya sebagai pusat Kerajaan Sriwijaya dan juga dianggap sebagai cikal bakal Kesultanan Melayu serta mempunyai andil besar dalam keruntuhan Majapahit dan pendiri kerajaan Islam (Demak) di Jawa, sehingga kesultanan Palembang dianggap pula sebagai kesultanan Melayu-Jawa. ${ }^{33}$

\section{METODE PENELITIAN}

Penelitian ini menggunakan metode kualitatif dengan pendekatan yang digunakan dalam penelitian ini adalah fenemologis. Penelitian ini bertujuan untuk menganalisis bagaimana keberadaan Islam terhadap budaya lokal sedekah serabi di Empat Lawang, selain itu untuk mengetahui bentuk komunikkasi spiritual dalam tradisi sedekah serabi yang dilakukan masyarakat Empat Lawang, selanjutnya untuk mengetahui makna filosofis sedekah serabi sehingga bisa dilestarikan hingga saat ini. Penelitian ini dilakukan di desa Simpang Perigi

32 Coedes, George, La Royaume de Crivjaya, BEFEO: Tome XVIII, 1918.

33 Husni Rahim, Sistem Otoritas Administrasi Islam: Studi Tentang Pejabat Agama Masa Kesultanan dan Kolonial Palembang, Ciputat: PT Logos Wacana Ilmu, 1998, h.7.
Empat Lawang, dengan melakukan observasi, wawancara mendalam ke tokoh ketua adat (jurai Tuo), Bupati, dan Kepala Dinas Pendidikan dan Kebudayaan dan masyarakat di Empat Lawang.

\section{HASIL DAN PEMBAHASAN}

Secara individual dan sosial manusia dilahirkan manusia tidak dapat dilepaskan dari religi atau sistem kepercayaan. Manusia sejak dilahirkan memiliki kecenderungan untuk mempercayai hal-hal yang gaib, hal-hal yang memiliki kekuatan supranatural dan sesuatu yang dijadikan objek persembahan. ${ }^{34}$ Agama dan dan sistem kepercayaan terintegrasi dengan kebudayaan. Menurut Saefudin Anshari agama menyajikan sistem credos, yaitu sistem kepercayaan yang berkaitan dengan sesuatu yang metafisik. Perwujudan keyakinan itu berkaitan dengan sistema ritus ,yaitu pola peribadatan dalam bentuk aktivitas fisik dan hati, serta bacaan-bacaan yang bernilai doa. Dalam hubungannya dengan pengembangan nilai-nilai agama, setiap agama menganjurkan manusia bergaul dengan sesame manusia dengan cara yang baik dan penuh kedamaian. ${ }^{35}$

Agama merupakan bagian dari kebudayaan masyarakat karena istilah budaya sebenarnya berkaitan dengan sistem ide atau nilai-nilai yang dianut

34 Abidin Zaenal Yusuf, dan Ahmad Beni Saebani, Pengantar Sistem Sosial Budaya, (Bandung: Pustaka Setia, 2014, h.82.

35 Saifudin, Endang Anshari, Wawasan Islam Pokok-Pokok Pikiran Nama Islam dan Umumnya, (Jakarta: Raja Grafindo Persada, 1993), h.12. 
oleh kelompok masyarakat, sehingga dapat dikatakan sebagai perwujudan budaya lokal.

E.B.Taylor mengatakan bahwa kebudayaan merupakan keseluruhan yang kompleks yang didalamnya terkandung pengetahuan, kepercayaan, kesenian, moral, hukum, adat istiadat, dan kemampuan lain yang didapat oleh seseorang sebagai anggota masyarakat. ${ }^{36}$ Bahkan Guztav Klemm $^{37}$ menyebutkan bahwa adat budaya dapat didefinisikan sebagai adat istiadat. Keanekaragaman adat etnik sehingga memberi pembenaran adat sebagai sumber identitas yang khas. Agama sebagai kajian ilmiah EB Taylor ${ }^{38}$ mengungkapkan dalam pendapatnya bahwa sebagai kepercayaan terhadap adanya wujud-wujud spiritual.

Agama dan kepercayaan merupakan dua hal yang adadalam diri manusia. Agama merupakan bagian dari kehidupan bangsa Indonesia yang berperan besar dalam membentuk jiwa dan pandangan hidup manusia Indonesia. Durkheim mengatakan bahwa agama sebagai satu kesatuan dan sistem kepercayaan dan prakteknya yang dihubungan dengan sesuatu bersifat suci (sakral) dan disatukan dalam sebuah komunitas sosial dengan kepatuhan/ketaatan atau individu yang

36 Yusuf Zaenal Abidin dan Beni Ahmad Saebani, Pengantar Sistem Sosial Budaya di Indonesia, (Bandung: Pustaka Setia, 2012), h.39.

${ }^{37}$ Charles Winich, 1977, h.225.

38 Betty R. Schraf, Kajian Sosiologi Agama, (Yogyakarta Tiara Wacana, 1995), h.30. ada di dalamnya terhadap segala perintah dan larangan. Karena agama sifatnya yang sangat pribadi, terselubung dan kadang-kadang diliputi oleh hal-hal yang bernuansa mitologis atau spiritual. Kualitas etos seseorang amat ditentukan oleh nilai-nilai kepercayaan yang melekat pada dirinya, yang dalam bahasa agama, hal ini disebut sebagai aqidah.

Pada masyarakat Empat Lawang sebelum Islam datang penduduknya kebanyakan menganut kepercayaan animisme dan dinamisme. Sebelum Islam datang,tradisi sedekah serabi dilakukan dalam bentuk sesajen, atau ritual khusus. Jeroen Peters ${ }^{39}$ sepakat bahwa masyarakat di Uluan Palembang pada abad ke-19 masih mempercayai kekuatan gaib yang berhubungan dengan pertanian. Ada ritual pembuatan ladang pertanian, penanaman, panen disertai sesaji dan selamatan. Namun kemudian setelah Islam datang tradisi sedekah serabi mengalami peleburan budaya, setiap sedekah rasa syukur dengan dimasukkannya doa-doa Islam di dalamnya sehingga setelah Islam berkembang di wilayah tersebut antara tradisi dan agama di abad ke-20 masih menjadi perdebatan didaerah tersebut karena berbau sinkretik. ${ }^{40} \mathrm{Hal}$ ini sejalan dengan pendapat Franz Susesno ${ }^{41}$ mengatakan bahwa kentalnya warna animisme dan dinamisme dalam tradisi

\footnotetext{
${ }^{39}$ Jeroen Peters, Kaum Tuo dan Kaum Mudo Perubahan Religius di Palembang 1821-1942, (Jakarta: INIS, 1997), h. 195.

${ }^{40}$ Wawancara, Vebri al Lintani, Palembang, 5 September 2019.

${ }^{41}$ Franz Magnis-Suseno, Etika Jawa: Sebuah Analisa Falsafi Tentang Kebijaksanaan Hidup Jawa, (Jakarta: Gramedia, 1999), h.1.
} 
tidaklah kemudian dimaknai sebagai bentuk sinkretis, melainkan suatu bentuk dari kemampuan adaptasi kultural yang dimiliki oleh masyarakat setempat untuk mempertahankan nilainilai luhur yang melembaga dalam ritualitas kebudayaan masyarakat. Namun adanya pengaruh Hindu-Budha, animisme dan dinamisme berkaitan pula dengan tradisi yang pernah berkembang di wilayah tersebut.

Islam yang masuk ke Sumatera Selatan dan di terima mudah di tempat tersebut menunjukkan bahwa Islam dan budaya terdapat interaksi juga korelasi yang signifikan karena adanya keseimbangan bahwa Islam yang dibawa itu memiliki kemampuan diterima dengan budaya setempat. ${ }^{42} \mathrm{Hal}$ ini sesuai dengan pendapat Masnun Tahir, bahwa sebenarnya Islam lahir sebagai produk lokal yang kemudian diuniversalisasikan dan ditransendensi sehingga kemudian menjadi universal. Kemudian Islam dipersepsi oleh pemeluknya sesuai dengan pengalaman, problem, kapasitas, intelektual, sistem budaya, dan segala keragaman masingmasing di dalam komunitas. ${ }^{43}$

Islam di Sumatera Selatan juga mengalami proses interaksi dan terjadi pergulatan yang serius antara Islam dan kepercayaan-kepercayaan pra Islam, negoisasi Islam dan budaya lokal serta proses saling mempengaruhi satu sama

\footnotetext{
${ }^{42}$ M. Dien Madjid, Disertasi Progress, Unusia, 10 Maret 2020

${ }^{43}$ Masnun Tahir, "Pergumulaan Hukum Islam dan Budaya Sasak Mengarifi Fiqih Islam WetuTelu," Jurnal Istiqra (Jakarta :Ditjen Pendidikan Tinggi Islam Direktorat Pendididkan Tinggi Islam), Vol. VI, (Januari 2007), h. 175-176.
}

lainnya. Masyarakat desa Gunungmerakso Baru dan desa Simpangperigi, Empat Lawang yang sebelumnya menganut animisme, dinamisme, pengaruh Melayu, Hindu juga tampak dalam tradisi lokal, sehingga terjadi percampuran (asimilasi) budaya lokal dengan budaya asing dalam hal ini budaya Islam sehingga membentuk identitas baru tanpa menghilangkan identitas asli.

Secara historis kedatangan Islam dengan ajaran-ajarannya di Nusantara dihadapkan pada realitas yang telah terbentuk bahkan mengakar secara kuat dalam sendi kehidupan masyarakat, sehingga perlu adanya kearifan pemahaman yang bertumpu pada local wisdom dengan cara menginterelasikan nilai-nilai ajaran agama yang sudah berkembang.

Kepercayaan ini sudah lama mengakar sejak dahulu kala di Nusantara. Pada masyarakat pedalaman di Nusantara telah memiliki konsep ke Tuhan-an (beragama), yaitu agama asal.(agama lokal). Menurut Agus Sunyoto agama asal di nusantara pada umumnya memuja sesembahan taya, kosong, swung, awing-uwung. (agama kapitayan). ${ }^{44}$ Hal ini juga dapat kita amati pada masyarakat Jawa misalnya kehidupan beragama sinkritisme sangat terlihat jelas. Hal ini mugkin disebabkan karena sikap lentur orang Jawa terhadap agama dari luar. Orangorang jawa berturut-turut menerima agama Hindu, Budha, Islam dan Kristen, lalu menjawakan semuanya. Hal ini dapat dilihat betapa pemujaan

44 Agus Sunyoto, Wawancara, Jakarta, 15 September 2019. 
roh halus masih ada di tingkat terdalam psikologi masyarakat Jawa. Di kalangan mereka dikenal ungkapan:" sedaya agami kemawon"... Walaupun 90\% penduduk menganut Islam, mereka termasuk "wong abangan", yang menganut kepercayaan tradisional berkedok Islam." Hal ini terbukti dengan masih berlanjutnya tradisi selametan...." . Kutipan tersebut mencerminkan keyakinan sejumlah ahli Indonesia akan aksioma yang menyatakan bahwa Islam Jawa bersifat sinkritis. Dasar aksiomanya adalah keyakinan tentang animisme, Hinduisme, Budhisme, dan Islam telah sedemikian rupa membentuk lapisan budaya Jawa. Clifford Geertz berpendapat bahwa sinkritisme di Jawa dikembangkannya melalui trikotomi, abangan-santri-priyayi dimana kehidupan santri-priyayi untuk melihat hubungan sosio religius dan perkembangan Jawa. ${ }^{45}$ Di Bali juga dapat kita jumpai budaya seni tari sanghyang, dimana jenis tari tersebut sakral sarat dengan nila-nilai ajaran spiritual prasejarah yang mengemas keyakinan, kepercayaan dalam bentuk kesenian.Penari dikendalikan oleh kekuatan roh yang ada di dalm tubuhnya dengan tujuan dipentaskan untuk membebaskan masyarakat dari pengaruh jahat.

Begitu pula halnya dengan ritus yang ada di dalam sedekah serabi, dimana sebelum melakukan sedekah, seseorang biasanya memiliki nazar tertentu. Dan dalam sedekah serabi ada

${ }^{45}$ Muhaimin AG, Islam daam Bingkai Budaya Lokal Potert Dari Cirebon, Ciputat: PT Logos Wacana Ilmu, 2002,h.2. dua macam, ada sedekah serabi kebanyakan yang ladzim, ada yang disebut dengan sedekah petunggu. Di dalam sedekah serabi petunggu ini, biasanya meminta petunjuk ketua adat atau jurai tuo untuk memohon doa dengan menggunakan persyaratan tetentu seperti kemeyan, ayam hitam dan lain lain sebagai syarat agar dapat disembuhkan dai penyakit yang diderita karena tak sembuh-sembuh. ${ }^{46}$

Komarudin Hidayat berpendapat bahwa $^{47}$, dalam kacamata sosioantropologis, persinggungan antara agama dan budaya sebenarnya merupakan sebuah keniscayaan. Sebagai sebuah -katakanlah- produk yang bersifat keilahian (divine), agama tentu diklaim sebagai seperangkat ajaran yang murni dan otentik. Meski demikian, patut diingat bahwa entitas agama yang (diklaim) murni dan otentik itu pasti membutuhkan sarana kulturalsosiologis untuk bisa sampai pada manusia. Dalam konteks yang demikian inilah persinggungan antara agama dan budaya menjadi tidak terelakkan. Maka menjadi wajar jika sebuah agama identik dengan kebudayaan masyarakat tertentu. ${ }^{48}$ Hal tersebut sejalan dengan pendapat Vilferedo mengatakan bahwa agama dari sudut pandang sosio antropologi atau ilmu sosial pada umumnya agama adalah berkaitan dengan kepercayaan (belief) dan

\footnotetext{
${ }^{46}$ Usman, wawancara dengan Jurai tuo di Empat Lawang, 20 September 2019

${ }^{48}$ Nurohcman, "Relasi Agama dan Budaya", Artikel, 2018 diakses dari https://beritagar.id/artikel/telatah/memaknairelasi-agama-dan-budaya
} 
upacara ritual yang dimiliki bersama oleh suatu kelompok masyarakat. ${ }^{49}$

Masyarakat Nusantara merupakan bangsa yang religius. Religiusitas masyarakat Nusantara tercermin dalam praktik agama asal dan agama lokal. Bahkan pada setiap fase kehidupan manusia diungkapkan dengan bentuk syukur pada sang pencipta. Dalam tradisi masyarakat Nusantara setiap pergantian waktu dan perubahan fase dalam kehidupan sering kali pada saatsaat penting yang terjadi dalam sejarah kehidupan dicermati dari ritus-ritus yang diadakan sebagai perayaan syukur seperti upacara slametan ${ }^{50}$ atau tradisi makan bersama, prosesi dengan bendabenda keramat dan sebagainya. Begitu pula dalam tradisi kehidupan masyarakat desa Gunungmerakso Baru dan desa Simpangperigi Empat Lawang, pada saat-saat penting yang terjadi dan biasanya setiap pergantian waktu dalam kehidupannya sering melakukan ritusritus sebagai perayaan syukur dengan tujuan membayar nazar atau membuat nazar. Tradisi sedekah serabi merupakan tradisi dalam membayar niat atau membuat nazar. Setelah nazar tercapai ungkapan syukur diwujudkan dengan makan-makan dan berkumpul bersama. Pada umumnya sedekah serabi dilaksanakan masyarakat berziarah dahulu ke makam puyang (leluhurnya) dengan membawa kue serabi berjumlah 44 buah.

${ }^{49}$ Amri Marzali, "Agama dan Kebudayaan", Jurnal UMBARA: Indonesian Journal Of Antrhoropology, 2017.

${ }^{50}$ Geertz, The Religion of Java, (Yogyakarta: Komunitas Bambu, 2009).
Tradisi lokal seperti tradisi sedekah serabi yang menjadi sebuah budaya lokal saat ini diangkat menjadi warisan tak benda PBB. Dalam dua tahun terakhir sejak 2018 tradisi sedekah serabi ini mulai dilestarikan kembali oleh pemerintah di desa Gunungmerakso Baru dan desa Simpangperigi, Empat Lawang. Sejauh penelitian yang penulis temukan belum ada penelitian yang menemukan jejak sejarah tentang kapan tradisi sedekah serabi dimulai. Namun tradisi sedekah serabi ini telah dilakukan sebelum Islam datang ke wilayah tersebut. ${ }^{51}$ Tradisi sedekah serabi yang sudah menjadi tradisi Islam lokal menjadi sebuah budaya lokal yang sampaikini masih ada dan geliat budayanya akhirakhir ini semakin dibangkitkan. ${ }^{52}$

Ditengah maraknya globalisasi, munculnya gerakan radikalisme yang menganggap bahwa tradisi itu tidak praktis, dan mengotori agama. Agama menjadi sebuah ajaran yang murni. Namun tradisi lokal sedekah serabi tetap bertahan di antara kedua sisi ini yaitu ditengah panasnya realitas sosial yang retak dan ragu karena purifikanisme.

Hal ini sejalan dengan konsep Pribumisasi Islam yang dikemukakan oleh Abdurrahman Wahid $^{53}$ yang menyatakan bahwa dalam pribumisasi Islam tergambar bagaimana Islam sebagai ajaran normatif yang berasal

\footnotetext{
${ }^{51}$ Vebri Lintani, Wawancara Pribadi, Palembang, 6 September 2019.

${ }^{52}$ Jungcik, Wawancara Pribadi dengan Bupati Empat Lawang, di Tebing Tinggi, 8 Juli 2020

53 Ainul Fitriah, Teosofi: Jurnal Tasawuf dan Pemikiran Islam, Vol.III, No. 1 Juni 2013
} 
dari Tuhan diakomodasikan ke dalam kebudayaan yang berasal dari manusia tanpa kehilangan identitasnya masingmasing. Pribumisasi Islam ini merupakan upaya untuk merespon perubahan-perubahan secara lokal maupun global dan sikap keberagamaan secara positif dan kreatif. ${ }^{54}$ Oleh sebab itu perlu kiranya untuk diteliti lebih jauh baik budayanya, sosial resilience yang membentuk perubahan. Beberapa diskursus terkait pendapat-pendapat mengenai hubungan antara Islam dan budaya lokal seperti dikemukakan oleh Faisol Ramdhoni (Islam sehari-hari): Islamisasi dan merangkul budaya, Milal Bizawie (Islam khas Indonesia dan teori): didakwahkan, kontektualisasi, merangkul budaya, memberangus budaya, memperkaya dan mengislamkan tradisi dan budaya, serta Islam yang telah melebur dengan tradisi, Abdurrahman Wahid: pribumisasi Islam yang meminjam "bentuk budaya" lokal, Azyumardi Azra: vernakularisasi, primbumisasi membumi ke dalam bentuk budaya, Islam embedded (tertanam) dalam budaya Indonesia, Mahrus El Mawa (pemikiran khas Indonesia): akulturasi dan sosialisasiajaran Islam, Oman Fatturahman (Islam empirik yang terindegenisasi): kontektualisasi, indegenisasi, vernakularisasi, Afifuddin Muhajir (fikih Nusantara): Islam membumi di Nusantara, Irham (Islam faktual): menyebarkan Islam, Islam diimplementasikan dan dikembangkan

54 Umaruddin Masdar, Membaca Pikiran Gusdur dan Amin Rais tentang Demokrasi,(Yogyakarta: Pustaka Pelajar, 1999), h. 124. di Nusantara. Ishom Yusqi: Islam Nusantara sebagai istilah/pendekatan: menyempurnakan budaya. ${ }^{55}$

\section{Sedekah Serabi Empat Lawang}

Sedekah merupakan kata yang familiar di kalangan umat Islam. Kata sedekah diambil dari bahasa Arab yaitu shodaqoh berasal dari kata "sidq", siddiq yang berarti kebenaran. Menurut BAZNAS No.2 tahun 2016, sedekah adalah harta atau non harta yang dikeluarkan oleh seseorang atau badan usaha di luar zakat untuk kemaslahatan umum. ${ }^{56}$

Sedekah serabi merupakan salah satu budaya lokal Empat Lawang. Sedekah dalam bahasa Arab:صدقة; diterjemahkan dari kata"sadakah". Sedekah merupakan harta yang diberikan secara sukarela oleh pemiliknya baik peruntukannya dibatasi (ditentukan) maupun tidak dibatasi. Sedekah merupakan pemberian harta pada orang-orang fakir miskin, orang yang membutuhkan, atau pihak-pihak lain yang berhak untuk menerima sedekah tanpa disertai imbalan, tanpa paksaan, tanpa batasan jumlah, kapan saja dan berapapun jumlahnya.

Dalam Islam sedekah sangat dianjurkan. Dengan bersedekah hubungan bersosial menjadi lebih baik. Bersedekah menjauhkan diri dari sifat sombong dan angkuh. Keutamaan bersedekah selain mendapatkan pahala di sisi Allah, sedekah merupakan

\footnotetext{
${ }^{55}$ Khabibi Muhammad Luthfi, Islam Nusantara: Relasi Islam dan BudayaLokal, dalam Jurnal Shahih, Vol. I No.1, januari-Juni 2016, h.8.

56 Badan Amil Zakat Nasional, Artikel dari https://baznas.go.id/sedekah diakses 15 Juni 2021.
} 
bentuk rasa syukur atas rezeki dan nikmat yang diberikan Allah pada hamba-Nya. Sedekah serabi merupakan warisan budaya yang mengandung nilai leluhur berupa ketakwaan kepada Allah SWT dan bersyukur apabila sudah dikabulkan permintaannya apabila membayar rezeki kepada sesama, bersilaturahmi dengan kerabat dan menanamkan sikap gotong royong.

Tradisi Sedekah Serabi di masyarakat Empat Lawang merupakan salah satu tradisi dan menjadi budaya lokal di kota Tebing Tinggi, Kabupaten Empat Lawang, Sumatera Selatan. Ciri khas ragam budaya masyarakat Empat Lawang ketika akan menghela hajatan besar (perkawinan) maupun hari raya lebaran sampai saat ini masih melakukan tradisi sedekah serabi.

Sedekah serabi sudah menjadi kewajiban bagi setiap masyarakat Empat Lawang sebelum melakukan hajatan atau sedekahan. Dan yang paling utama tujuan dari sedekah serabi membayar nazar atau tolak balak. Seperti halnya ketika menyambut bulan suci ramadhan dan hari raya lebaran, pelaksanaan tradisi itu sama halnya seperti proses sedekahan lainnya yaitu berisi doa-doa. Namun ciri khas nya adalah makan yang paling diutamakan dan yang paling disajikan adalah serabi ditambah dengan makanan pendamping, lainnya pisang goreng, bolu, kerupuk ubi merah, roti goreng, kecepol, agaragar. ${ }^{57}$

Sedekah serabi diyakini sudah ada sejak zaman dulu yang dilakukan jauh sebelum Islam berkembang pesat.datang

\footnotetext{
${ }^{57}$ Anggarini, Diah, "Sedekah Serabi”, Dari RRI, Feature Budaya Produksi RRI Palembang, 2018.
}

dan menjadi mayoritas menjadi pemeluk masyarakat di kabupaten Empat Lawang. Pada masa lampau masyarakat Empat Lawang banyak menganut kepercayaan animisme yang dipercaya pada kekuatan ruh phuyang leluhur serta dianggap masih dapat melindungi anak cucu meskipun sudah meninggal. Ketika tradisi akan dilakukan biasanya tuan rumah atau pemilik hajat menyilap atau membakar kemeyan. Kemudian pemilik hajat menyampaikan hajat kepada puyang leluhur, jika terkabul mak sedekah serabi dilakukan kembali. ${ }^{58}$

Empat Lawang memiliki tradisi banyak sedekah, atau kenduri dalam bahasa Melayu. Sedekah serabi merupakan salah satu sedekah yang sudah dilakukan sejak zaman nenek moyang. Sampai saat ini belum tahu sejak kapan itu dilakukan. Namun sebelum Islam datang tradisi sedekah serabi menjadi tradisi popular di masyarakat Empat Lawang. Adapun tujuan sedekah serabi ini membayar niat atau membuat niat atau bernazar. Misalnya nazarnya kalau dia nanti dapat panen yang banyak, dia sedekah serabi, kalau anaknya lulus sekolah dia akan sedekah serabi, hal itu dicetuskan di dalam sedekah serabi diawal, dan kemudian kalau nanti tercapai akan dibayar dengan sedekah serabi. Ada lagi sedekah serabi yang dilakukan nenek moyang zaman dulu sebelum Islam datang yaitu sedekah serabi petunggu. Sedekah serabi petunggu itu untuk pengobatan . kalau di dalam unsur

58 Anggarini, Diah, "Sedekah Serabi", Dari RRI, Feature Budaya Produksi RRI Palembang, 2018 
budaya disebut ritus pengobatan. Misalnya seseorang sakit,belum sembuh juga maka mereka dibawa ketua adat dan atau jurai tuo, nanti jurai tuo tersebut akan meminta petunjuk dengan ritus spiritual yaitu berkomunikasi dengan phu-yang maka jurai tuo akan dapat petunjuk dan mengatakan bahwa ini harus dilakukan sedekah serabi petunggu sebanyak 44 buah serabi. Maka diadakan sedekah serabi tersebut. ${ }^{59}$

Masyarakat percaya bebayar nazar itu sudah menjadi kewajiban, jika tidak maka akan mendapat kafarat atau kualat. Saat ini masyarakat Empat Lawang secara penuh menjalankan agama Islam sedekah serabi masih dilakukan, namun permohonan dengan pu hyang digantikan dengan doa-doa kepada Allah SWT. Lazimnya sedekah serabi dilaksanakan di malam jumat, sehabis sholat magrib. Malam jumat dipercaya kembalinya ruh-ruh pu-hyang ke rumah untuk menjenguk anak cucunya. Sementara jika dikaitkan dengan agama Islam, hari jumat merupakan waktu yang paling tepat untuk beroda dan bersyukur. Oleh karena itu sedekah serabi sebelum dan sesudah masa Islam di kabupaten empat lawang tetap dilaksanakan di malam Jumat. ${ }^{60}$

Menurut Vebri sebelum Islam datang diyakini malam jumat diyakini datang ruh-ruh pu hyang tersebut, dan biasanya kamis sore mereka ziarah, malamnya ruh-ruh itu datang dan kemudian sedekah serabi. Diyakini

${ }^{59}$ Vebri Al Lintani, Wawancara, Palembang, 5 September 2019.

${ }^{60}$ Vebri Al Lintani, Wawancara, 2019 sebelum Islam masuk pu-hyang, puhyang itu masih bisa membantu atau menjaga anak cucunya, sehngga harus disedekahi. Karena itu dipilih malam jumat, kemudian setelah masuk Islam sedekah serabi masih diteruskan dengan tata cara yang berubah. Setelah masuk Islam Pada era pra Islam, sedekah serabi menggunakan kemeyan, setelelah masuk Islam disesuaikan dengan syariat Islam. Dengan berdoa, membaca yasin ditutup dengan berdoa. Setelah berdoa minta keselamatan, niatnya membayar nazar. Pada tahun 90-an kebawah sering dilakukan untuk kebutuhan ritus dengan mewujudkan rasa syukurnya pada sedekah serabi. ${ }^{61}$

Dengan demikian penulis menyimpulkan bahwa sedekah serabi adalah bermohon membuat nazar dan bersyukur, dengan bersedekah mengajak sanak saudara kerabat makan bersama. Selain itu juga sedekah serabi dilakukan pada saat menjelang memasuki bulan Ramadhan hingga hari raya lebaran dengan alasan tolak balak. Serabi di kabupaten empat lawang umumnya terdiri atas beberapa jenis seperti serabi 44, serabi bakhi, serabi baru atau qodak atau serabi biasa. Serabi 44 berbentuk bulat dan lepeng berwarna putih, dengan ukuran sekitar berdiameter $10 \mathrm{~cm}$ dan lebih besar dari ukuran serabi biasa. Disebut 44 karena jumlah 44 saat dihidangkan, sedangkan serabi lain sudah dicampur dengan kuah santan, bentuknya juga bulat lempeng dengan ukuran sekitar $5 \mathrm{~cm}$. Serabi 44 tidak langsung dicampur dalam kuah tetapi ditaruh di tengah

${ }^{61}$ Vebri Al Lintani, Wawancara, 2019 
Komunike, Volume XIII, No. 1 Juni 2021

piring. Serabi biasa disusun mengelilingi ke serabi 44 tersebut. Serabi 44 dikhususkan dibagikan sedikit-sedikit pada para sesepuh atau para tetuo masyarakat sedangkan serabi biasa untuk konsumsi masyarakat umum.

Cara pembuatan serabi tersebut yaitu serabi terbuat dari tepung beras dan sedikit kapur makan,bahan-bahan dicampur dengan air panas dan dingin diaduk serta dibentuk dengan selera masyarakat masing-masing misanya dengan bentuk lupis atau bentuk lempeng. Untuk kuah serabi santan dapat ditambahkan dengan gula merah dan gula putih sebagai pemanis. Tapi berbeda halnya dengan membuat kuah santan pada umumnya, kuah serabi dimasukkan dalam keadaan kuah ketika air sudah mendidih dan akan terasa sedap apabila dicampur dengan durian.

\section{Makna Sedekah Serabi Secara Filosofis}

Sedekah serabi merupakan warisan budaya yang mengandung nilai luhur. Kue Serabi terbuat dari bahan tepung beras. Tepung beras merupakan sumber kehidupan. Dari sisi sedekah mengandung makna berupa ketakwaan kepada Allah SWT dan bentuk rasa syukur pada Allah karena sudah dikabulkan permintaannya. Jumlah 44 mengandung makna angka 4 berarti ketepatan yaitu tepat janji yang dilunasi, tepat dalam bersyukur. Dalam sedekah serabi tersebut mengundang dan mengumpulkan sanak kerabat untuk makan bersama, hal ini mengandung unsur silaturahmi dan kegotongroyongan, dan ukhuwah Islamiyah.

Oleh karena itu sampai saat ini sedekah serabi masih tetap dilaksanakan, karena nilai-nilai Islam ada di dalamnya. Sejak Islam datang, ritual seperti kemeyan dan lain lain tidak digunakan lagi dan doa-doa diisi dengan doa-doa tahlil atau doa secara Islam. Di daerah desa Kunduran misalnya mereka kebanyakan mengikuti golongan kaum tuo yaitu pengaruh Nadhlatul Ulama lebih dulu ada di sana dan masih melihat secara jernih. Sebelum Islam datang, masyarakat EmpatLawang sebagian melihat puhyang bagian dari penghormatan terhadap leluhur, bukan pencipta. Setelah Islam masuk hal itu dianggap syirik. Karena dikuatirkan menyembah pu-hyang dan argument tersebut begitu kuat. Oleh sebab itu sebagian masyarakat disana khususnya di desa Perigi tidak mentolerir hal itu dan tidak percaya dengan ritus tersebut.

Tradisi lainnya di desa Kunduran biasanya sebelum melakukan sedekah serabi, mereka melakukan ziarah dahulu ke makam pu-hyang atau leluhur. Setelah ziarah mereka mengambil tanaman "pudding" yang daunnya bewarna hijau kuning, lalu diambil ranting diikatkan ditangga sebagai simbol untuk mengundang leluhur datang. Biasanya masyarakat melakukan sedekah serabi kebanyakan dengan tujuan mencuci dusun, tolak balak, dimana dusun tersebut sudah dianggap kotor,adanya kemarau panjang dianggap kutukan dan minta diturunkan hujan. Masyarakat Empat Lawang biasanya membuat persembahan dan sedekah kebanyakan sambil membawa 
pusaka-pusaka, biasanya dilaksanakan di pinggir sungai ulu musi atau di pantai Bungen.

\section{Komunikasi Spiritual Dalam Budaya Lokal Sedekah Serabi}

Secara etimologis istilah komunikasi atau dalam bahasa Inggris "communication" berasal dari bahasa latin communication bersumber dari kata 'communis' yang berarti sama". Sama yang dimaksud disini adalah dalam pengertian "sama makna". Dalam komunikasi minimal harus mengandung "kesamaan makna" antara kedua belah pihak yang terlibat. Hal itu disebabkan karena komunikasi tidak bersifat informatf saja (to inform) yakni agar orang/komunikan mnegerti dan tahu, tetapi jua edukatif (to educate) dan persuasif (to influence), yaitu orang//komunikan bersedia menerima suatu paham atau keyakinan dan mempengaruhi untuk melakukan suatu tindakan. (Lajnah: 2013:6). ${ }^{62}$ Dalam proses komunikasi ada beberapa unsur fundamental antara lain: 1) komunikator: pelaku/orang yang menyampaikan pesan kepada orang lain. Dalam hal ini komunikator (encoder) mempunyai sifat encoding yaitu upaya komunikator dalam menafsirkan pesan (massage) yang akan disampaikan kepada komunikan agar komunikan dapat memahaminya.2) Message: pesan, berupa kata-kata, lambang-lambang, isyarat, tanda-tanda atau gambar yang disampaikan (dikomunikasikan). 3) Komunikan;

\footnotetext{
${ }^{62}$ Tafsir Al quran Tematik, Komunikasi dan Informasi, (Jakarta: Lajnah Pentashihan Mushaf Al uran, 2013), h. 7.
}

orang/pihak yang menerima pesan dan komunikator.Komunikator disebut juga dengan decoder yang punya sifat decoding yaitu suatu usaha komunikasi dalam menafsirkan pesan yang disampaikan oleh komunikator. 4) Medium; alat atau media yang digunakan untuk berkomunikasi agar hasil komunikasi dapat mencapai saran yang lebih banyak dan luas. (Lajnah: 2013: 7).

Sebagai makhluk yang beragama, manusia juga makhluk sosial dan makhluk yang selalu berinteraksi dan bermasyarakat karena senantiasa membutuhkan peran-peran pihak lain. Artinya berinterkasi sosial atau hidup berasyarakat mrupakan sesuatu yang tumbuh secara alamiah sesuai dengan fitrah dan kebutuhan manusia. Dalam perspektif Islam, komunikasi disamping untuk mewujudkan hubungan horizontal terhadap sesamamanusia, hablum minannas, juga digunakan untuk membnagun hubungan vertikal kepada Allah, hablum minallah. Komunikasi dengan Allah tercermin melalui ibadah wajib, seperti doa, shalatdan puasa, yang bertujuan untuk membentuk ketakwaan. Komunikasi dengan sesama manusia terwujud melalui penekanan hubungan sosial, muamalah ijtima'iyyah yang tercantum dalam semua aspek kehidupan manusia, seperti agama, budaya, politik, ekonomi, dan seni. ${ }^{63}$ Komunikasi tidak dapat dingkari bisa terjadi dimana saja dan dengan siapa saja. Bahkan manusia bukan saja dapat berkomunikasi dengan benda-benda, grafis, warna, dn dengan pribadi

\footnotetext{
${ }^{63}$ Lajnah, h. 136.
} 
(personal), namun manusia dapat berkomunikasi dengan makhluk yang bukan manusia. Misalnya dengan hewan,jin,malaikat, roh-roh para leluhur. Komunikasi ini disebut sebagai komunikasi metapersonal. Komunikasi metapesonal adalah komunikasi yang terjadi melampaui (atau dibalik) komunikasi yang lazimantar personal manusia. Seperti komunikasi anatara Allah dengan ruh, malaikat, jin, manusia dengan hewan, dan manusia dengan roh-roh leluhur. ${ }^{64}$

Seperti agama lain Islam aalah kekuatan spiritual dan moral yang mempengaruhi, memotivasi danmewarnai tingkah laku individu. Menguraikan tradisi Islam yang tumbuh di kelompok masyarakat tertentu adalah menelusuri karakteristikIslam yang terbentuk melalui tradisi populer. Dalam hal ini diketahui unsur pembentuk tradisi dan unsur pembentuk tradisi Islam. Tradisi secara umum dipahami sebaga pengetahuan, doktrin, kebiasaan, praktek dan lain-lain yang diwariskan turun-temurun termasuk cara penyampaian pengetahuan, doktrin dan praktek tersebut. ${ }^{65}$

Dalam suatu bangsa tidak akan memiliki ciri khas tersendiri tanpa adanya budaya yang dimiliki dan budaya itu pun berkembang sesuai dengan kemajuan zaman yang semakin modern kebudayaan yang berkembang dalam satu bangsa disebut dengan kebudayaan lokal yang merupakan sebuah hasil cipta. karsa dan rasa yang

\footnotetext{
${ }^{64}$ Lajnah 2013, h.127-129.

${ }^{65}$ Funk dan Wagnalss (1984), standard desk Dictionary, Cambige: harper dan Row.
}

tumbuh dan berkembang di suku bangsa di daerah tersebut.

Di dalam kebudayaan pasti menganut suatu kepercayaan yang disebut dengan agama-agama sendiri ialah sistem atau prinsip kepercayaan kepada Tuhan atau disebut juga dengan nama dewa atau lainnya ke jalan kebaktian, kewajiban yang bertalian yang kepercayaan yang dianut oleh suatu suku atau etnis tersebut.

Budaya lokal sedekah serabi di Empat Lawang di dalamnya terdapat hubungan spritiual sebagai bentuk komunikasi antara Tuhan dan alam juga manusia. Dalam hal ini, sedekah serabi memiliki bentuk komunikasi spiritual antara jurai tuo dan puyang yang dianggap sebagai leluhur untuk menyampaikan doa sebagai wasilah kepada Allah sang pencipta. Komunikasi diartikan sebagai suatu preoses atau interaksi dua arah atau lebih dari seseorang, kelompok, masyarakat agar terjalin hubungan dengan orang lain. Dialog kebatinan yang dilakukan jurai tuo tersebut bersifat trandensi antara manusia dengan roh. Melalui media serabi, doadoa yang dipanjatkan oleh jurai tuo meminta kepada pu -hyang sebagai wasilah untuk menyampaikan hajat kepada sang pencipta. Komunikasi tidak didominasi oleh manusia bisa juga antar binatang atau jenik makhluk lainnya. Pada manusia komunikasi dibangun atas kepentiingan dari pihak-pihak tertentu dengan berbagai media. Media dalam komunikasi diartikan sebagai alat bantu agar tujuan-tujuan tersebut dengan mudah lebih dipahami dan di mengerti. Sedangkan spiritual dimaknai sebagai 
kegiatan manusia yang bersifat trasendensi, sulit diphamai dimengerti oleh logika dan pikiran orang lain dalam bentuk tanda dan penanda. ${ }^{66}$

Seperti agama lain, Islam adalah kekuatan spiritual dan moral yang mempengaruhi, memotivasi dan mewarnai tingkah laku individu. Menguraikan tradisi Islam yang tumbuh di kelompok masyarakat tertentu adalah menelusuri karakteristik Islam yang terbentuk melalui tradisi populer. Dalam hal ini diketahui unsur pembentuk tradisi dan unsur pembentuk tradisi Islam. Tradisi secara umum dipahami sebaga pengetahuan, doktrin, kebiasaan , praktek dan lain-lain yang diwariskan turun-temurun termasuk cara penyampaian pengetahuan, doktrin dan praktek tersebut. Dalam hal ini bisa kita amati terutama pada masyarakat Empat Lawang meyakini keberadaan pu-hyang. Menurut Vebri, dari cerita legenda pu-hyang disebutkan ada 3 jenis, pertama yang dimaksud dengan pu-hyang itu adalah arwah leluhur atau nenek yang disebut "malekat-malekat", yang kedua puyang berarti sebutan untuk generasi ketiga diatas orang tua yang sudah meninggal. Mereka belum tentu sakti. Ketiga, puyang sebutan untuk mereka yang menjadikan dusun atau pendekar sakti yang namanya melegenda dan pernah hidup dimasanya, dan dipercaya mereka itu menjaga dusun tersebut. Kisah mereka melegenda dalam sejarah Batanghari

66 I Nyoman Lodra, Tari Sanghyang Media Komunikasi Spiritual Manusia dengan Roh, Jurnal Harmoni, Puslitbang Bimas Agama dan Layanan Keagamaan Banda Litbang dan Diklat Kemenag, Vol. 1, No. 2 Juli -Des 2017.
Sembilan dan diyakini semua penduduk menjadi sumber pesan atau way of life, ideologi bagi masyarakat Empat Lawang. Seperti contoh dalam bahasa Empat Lawang: "Pesan puyang dikalo dahulu, jangan ngucak jemo. Setapak jangan diunduri. Jangan ganggu orang kalau diganggu jangan mundur setapakpun." Puyang kemiri berpesan "jangan nyappakan kaparan di ayik, jangan nyapakan miyang diulu tepian." Puyang Kemiri disini sebagai wasilah. Jika dikaitkan dengan keramat maka puyang itu menjadi media sumber penuntun kehidupan. ${ }^{67}$

Dengan demikian di dalam tradisi sedekah serabi terdapat pengaruh sinkkritis agama di dalam budaya sedekah serabi, dimana kepercayaan dan keyakinan masyarakat Empat Lawang terhadap keberadaan puyang masih diyakini. Sedekah serabi di Empat Lawang terdiri dari sedekah serabi biasa, sedekah serabi kebanyakan, sedekah serabi petunggu. Sedekah serabi petunggu masih sebagian dilakukan masyarakat ketika dalam hidupnya mengalami sakit yang tak juga sembuh.

Tradisi sedekah serabi merupakan tradisi ritus khas masyarakat di Empat Lawang yang dilakukan sebelum pra Islam sampai saat ini masih dilakukan masyarakat namun diberikan sentuhan Islam tanpa menghilangkan jejak kelokalannya dengan tujuan membayar nazar atau membuat nazar. Adanya jurai tuo tetap dianggap dan dipertahankan sebagai pemimpin adat. Komunikasi spiritual jurai tuo dalam sedekah serabi

${ }^{67}$ Vebri Al Lintani, Wawancara, 2019 
memiliki nilai religiusitas dalam Islam. Dengan berwasilah kepada puyang jurai tuo meminta petunjuk dan berdoa agar niat dan nazar yang dilakukan mendapatkan kemudahan. Dalam sedekah serabi doa-doa yang digunakan menggunakan doa tahlil, dan doa-doa Islam menunjukkan bahwa adanya eksistensi Islam yang kuat dimana nilainilai ketauhidan dan ketakwaan yang diwujudkan dalam bentuk syukur atas nazar yang telah dikabulkan terhadap Allah sang pencipta.

\section{Sejarah Asal Usul dan Nilai Filosofis Makna Empat Lawang}

Empat Lawang adalah nama salah satu kabupaten di wilayah provinsi Sumatera Selatan, Indonesia. Terletak di kota Tebing Tinggi. Kabupaten Empat Lawang diresmikan pada 20 April 2007 ini sebelumnya tergabung dalam Kabupaten Lahat. Ada berbagai suku yang berada di Empatlawang. Namun, suku Lintang merupakan suku mayoritas (55\%). Ditinjau dari asal katanya, empatlawang terdiri dari dua kata: empat dan lawang. Empat menunjukkan bilangan, sedangkan "lawang" memiliki dua makna. Pertama, bermakna pintu (kosa kata Jawa dan diserap dalam bahasa Palembang; Jawa), dan kedua, lawangan (bahasa lokal Lintang dan Besemah) yang bermakna pendekar; pahlawan atau tokoh. Empatlawang dapat juga bermakna empat pintu dan empat pendekar, empat pahlawan atau empat tokoh.

Jika menelaah sastra lisan tentang asal usul nama Empatlawang menjurus pada makna empat tokoh pendekar atau pahlawan penjaga empat pintu (penjuru) mata angin. Ada beberapa cerita lisan yang ditulis berikut ini. Cerita lisan pertama: lawang adalah lawangan atau pendekar atau pahlawan Dicuplik dari tulisan Ismail Majid, “Asal Mula Nama Empatlawang". ${ }^{68}$

Arti kata Lawang yang sesungguhnya adalah Lawangan atau Pamitan, yaitu orang yang terkemuka atau Sesepuh dan dapat pula diartikan Pahlawan. Berdasarkan dari cerita-cerita lisan, dapat diambil kesimpulan bahwa "Lawang" dapat diartikan sebagai: pendekar; pahlawan; pamit; dan pintu. Sedangkan angka empat menunjukkan bilangan yang dapat ditafsirkan sebagai lambang kepahlwanan, pertahanan, keberanian, persatuan, keseimbangan, kesetiaan, kekokohan, ketepatan, kerjasama, keterbukaan dan kegotongroyongan.

Nilai-nilai luhur yang bersumber pada cerita-cerita lisan tentang asal usul Empat Lawang tersebut di atas layak dijadikan sebagai dasar nilai dalam membangun kabupaten Empatlawang.

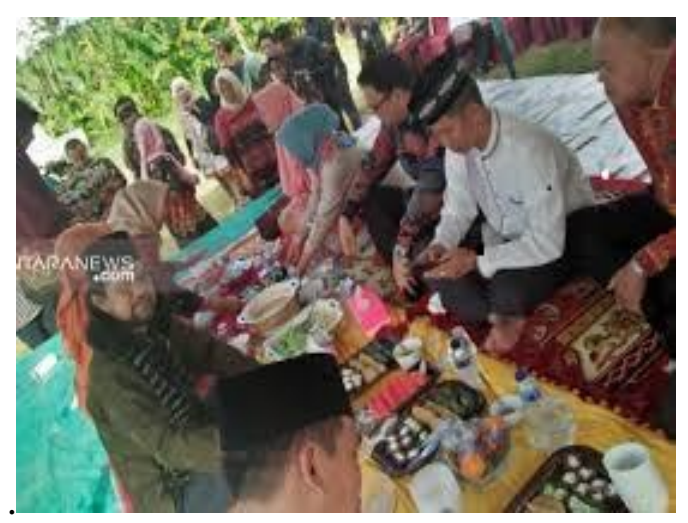

Gambar 1. Sedekah serabi yang diadakan Masyarakat Lintang Empat Lawang, April 2018

68 Vebri Al Lintani, Tradisi sedekah Serabi, 2018. 


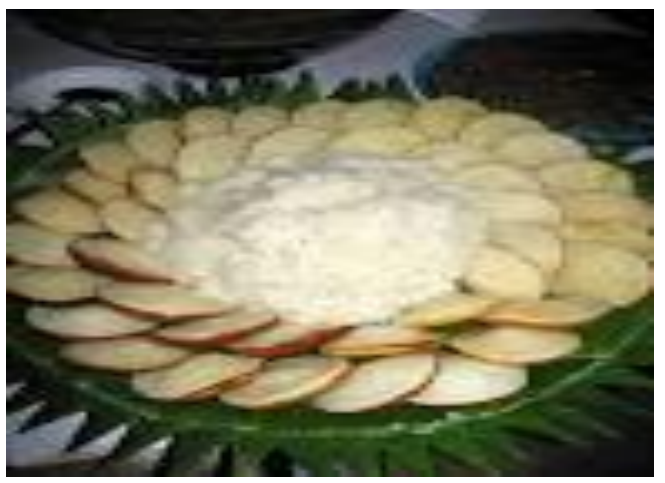

Gambar 2. Kue Serabi 44 dalam sedekah serabi

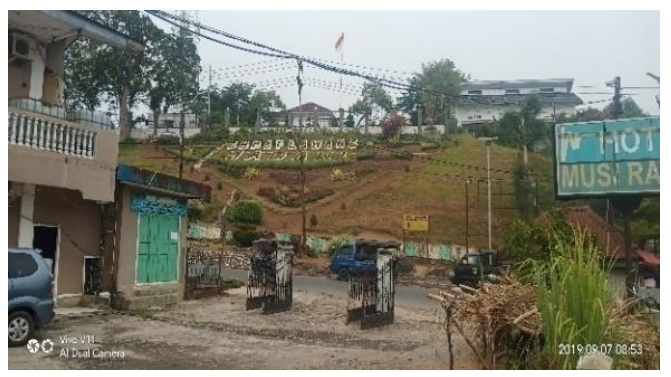

Gambar 3. Lokasi suku Lintang di Kabupaten Empat Lawang, Kota Tebing Tinggi, Sumatera Selatan

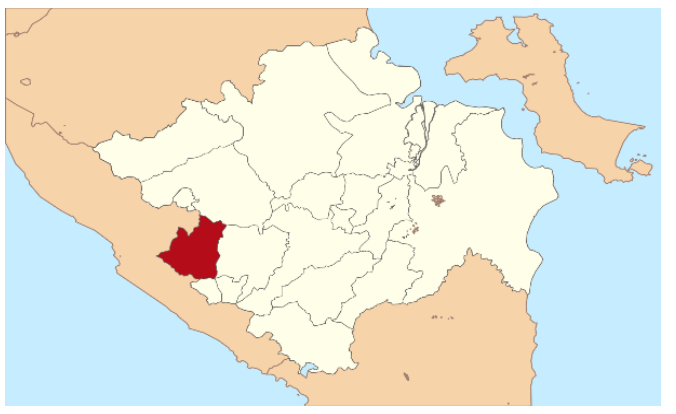

Gambar 4. Peta Lokasi Suku Lintang Empat Lawang, Sumatera Selatan

\section{E. KESIMPULAN}

Kedatangan Islam di Empat Lawang, bukan berarti merubah total semua tata cara dan seluruh adat serta tradisi lama di Empat Lawang. Namun keduanya terjadi proses asimilasi kebudayaan dan negoisasi kebudayaan dimana antara Islam dan tradisi lokal sedekah serabi membaur menjadi satu.
Adanya pengaruh sinkkritis agama di dalam budaya sedekah serabi, dimana kepercayaan dan keyakinan masyarakat Empat Lawang terhadap keberadaan puhyang masih diyakini. Sedekah serabi di Empat Lawang terdiri dari sedekah serabi biasa, sedekah serabi kebanyakan, sedekah serabi petunggu. Sedekah serabi petunggu masih sebagian dilakukan masyarakat ketika dalam hidupnya mengalami sakit yang tak juga sembuh.

Tradisi sedekah serabi merupakan tradisi ritus khas masyarakat di Empat Lawang yang dilakukan sebelum pra Islam sampai saat ini masih dilakukan masyarakat namun diberikan sentuhan Islam tanpa menghilangkan jejak kelokalannya dengan tujuan membayar nazar atau membuat nazar. Adanya jurai tuo tetap dianggap dan dipertahankan sebagai pemimpin adat. Komunikasi spiritual jurai tuo dalam sedekah serabi memiliki nilai religiusitas dalam Islam. Dengan berwasilah kepada pu-hyang jurai tuo meminta petunjuk dan berdoa agar niat dan nazar yang dilakukan mendapatkan kemudahan. Dalam sedekah serabi doa-doa yang digunakan menggunakan doa tahlil, dan doa-doa Islam menunjukkan bahwa adanya eksistensi Islam yang kuat dimana nilainilai ketauhidan dan ketakwaan yang diwujudkan dalam bentuk syukur atas nazar yang telah dikabulkan terhadap Allah sang pencipta.

Sedekah serabi memiliki makna filosofis yang melambangkan bahwa sedekah serabi memiliki makna Kegiatan sedekah Serabi di Empat Lawang memiliki dampak positif bagi kelangsungan nilai budaya untuk 
Komunike, Volume XIII, No. 1 Juni 2021

menambah rasa persatuan dan kesatuan masyarakat, sehingga kerukunan hidup dan toleransi tumbuh dan terjadi harmonisasi dalam keberagaman.

Ucapan terima kasih kepada: Bupati Empat Lawang, Dinas Pendidikan dan Kebudayaan, Ketua Adat Empat Lawang, masyarakat Empat Lawang yang telah membantu dalam memberi akses memanfaatkan data yang diperlukan dalam penulisan ini.

\section{F. DAFTAR PUSTAKA}

Azra, Azyumardi, Agama Dalam Keragaman Etnik di Indonesia, Jakarta: Balitbang Agama, 1998

Abdulah,Taufik, Sejarah Lokal di Indonesia, Yogyakarta: Gajah Mada Univ Press,1986

AG. Muhaimin, Islam daam Bingkai Budaya Lokal Potert Dari Cirebon, Ciputat: PT Logos Wacana Ilmu, 2002

Rahmat, M. Imdadun, Islam Pribumi, Islam Indonesia, dalam $\mathrm{M}$. Imdadun Rahmat (et al.), Islam Pribumi: Mendialogkan Agama Membaca Realitas," Jakarta: Erlangga, 2003, hlm. xx-xxi

Alifudin, Muhammad, Islam Buton, Interaksi Islam dan Budaya Lokal, Disertasi, UIN Sunan Kalijaga, 2006, dalam http://digilib.uinsuka.ac.id/15076/

Budiwanti, Erni, Islam Sasak, Yogyakarta: LKiS, 2000

Betty Scharf R, Kajian sosiologi Agama , 1945 pendapat A. Radclife Betty R Schraf Kajian Sosiologi Agama, Yogyakarta; Tiara Wacana 1995
Badrudin, Antara Islam Dan Kebudayaan, Jurnal Filsafat Islam: Historisitas Dan Aktualitas,UIN Sunan Kalijaga, (2014), hlm.

Bekki, A, Socio Cultural Changes in a Traditional Javanese Village, dalamLife in Indonesian Villages, In Institute of Asian Studies, Tokyo: Rikko (St. Pauls) University, 1975

Amin, Azim, Tradisi Sedekah sebagai bentuk Mensyukuri Nikmat Allah SWT dan Kesalehan Wong Palembang, Jurnal Kebudayaan dan Sastra Islam No.2 Juli 2008

Agung Setiyawan, Budaya Lokal Dalam Perspektif Agama: Legitimasi Hukum Adat ('Urf) Dalam Islam, Jurnal Esensi, Vol.13 No. 2, Juli 2012

Ariful, Anang Habib, The Principle Of Zakat, Infaq, And Shadaqah Accounting, 2016

Anggarini, Diah, "Sedekah Serabi", Dari RRI, Feature Budaya Produksi RRI Palembang, 2018, dalam content: //999@com.whatsapp.providerme dia/item/258364.

Endang Saefudin Anshari, dari buku Yusuf Zaenal Abidin dan Beni, Pengantar Sosial Budaya, Bandung: Pustaka Setia, 2013

Farida, Ida dan Rochmiatun, Endang,

$$
\text { dkk, Peradaban Islam Palembang, }
$$
JUSPI

(Jurnal Sejarah Peradaban Islam), No. 3 Vol. 1, 2019 
Komunike, Volume XIII, No. 1 Juni 2021

Hanafiah,Djohan, Melayu Jawa - Citra Budaya dan Sejarah Palembang, Jakarta: Grafindo Persada, 1995

Herusatoto, Budiono, Simbolisme Jawa, Yogyakarta: Ombak, 2007

Hefni, A. Harjani, Komunikasi Islam, Jakarta: Prenada, 2017

Ikram, Achadiati, Pemeliharaan Sastra Lama Masyarakat Masa Kini, Beberapa Masalah Perkembangan Ilmu Filologi Dewasa Ini, (Jakarta: Diktat Kuliah Fakultas Sastra Universitas Indonesia, 1993.

Groenveldt, W.P., Historical Notes on Indoensia and Malaya, Compiled From Chinese Sources, Jakarta: Bhratara, 1960

George Coedes, La Royaume de Crivjaya, BEFEO: Tome XVIII, 1918

Geertz,Clifford, Agama Jawa : Santri, Abangan dan Priyayi Dalam Kebudayaan Jawa, Depok: Komunitas Bamboo, 2013

Globalreligiusfuture, Penduduk Indonesia yang beragama Islam pada 2010 dari https://databoks.katadata.co.id/dat apublish/2019/09/25/indonesianegara-dengan-penduduk-muslim

Lajnah Pentatashihhan Mushaf Al Qur'an Badan Litbang Dan Diklat Kementrian Agama RI, Tafsir AlQur'an dan Tematik, Sinergitas Internal Umat Islam, Jakarta: Lajnah Petashihan Mushaf AlQur'an, 2017

Mondo, Laude Bauto, Perspektif Agama dan Kebudayaan dalam kehidupan masyarakat Indonesia suatu tinjauan sosiologi agama, dalam JPS Jurnal Pendidikan Ilmu Sosial, Vol. 23 No. 2, edisi Desember 2014

Nyoman I. Lodra, Tari Sanghyang Media Komunikasi Spiritual Manusia dengan Roh, Jurnal Harmoni, Puslitbang Bimas Agama dan Layanan Keagamaan Banda Litbang dan Diklat Kemenag, Vol. 1, No. 2 Juli -Des 2017

Portal resmi Pemerintah Kabupaten Empatlawang, situs Komunitas Lintang IV Lawang. (https://empatlawangkab.go.id/v2/ bkpsdm/).

Petters, Jeroen, Kaum Tuo dan Kaum Mudo Perubahan Religius di Palembang 1821-1942, Jakarta:INIS, 199

Rahim, Husni, Sistem Otooritas Administrasi Islam: Studi Tentang Pejabat Agama Masa Kesultanan dan Kolonial Palembang, Ciputat: PT Logos Wacana Ilmu, 1998

Setiyawan, Agung, Budaya Lokal Dalam Perspektif Agama: Legitimasi Hukum Adat ('Urf) Dalam Islam, Jurnal ESENSIA, Jurnal Ilmu-ilmu Ushuludin, Vol. 22 Juli 2012

Usman, Wawancara Pribadi, Tokoh adat /Jurai Tuo di Desa Perigi Lintang Empat Lawang, 6 September 2019

Vebri Al Lintani, Wawwancara, Palembang, 4 September 2019

Wahyuni, Perilaku Beragama (Studi sosiologi terhadap asimilasi 
Komunike, Volume XIII, No. 1 Juni 2021

Agama dan Budaya di Sulawesi Selatan, Makassar: Alaudin University Press, 2013

Ricklefs, Sejarah Indonesia Modern, Jakarta: Serambi, 2008

Rohimin dan Zubaidi, et.all., Penyerapan Nilai-Nilai Budaya Lokal Dalam Kehidupan Beragama di Bengkulu (Studi Tentang Tradisi Tabot di Bengkulu), Jakarta: Balai Penelitian dan Pengembangan Agama Jakarta, 2009

Sabara, "Islam Dalam Tradisi Masyarakat Lokal di Sulawesi Selatan", Jurnal Mimikiri, Vol. 4 No.1 2018

Saifudin, Endang Anshari, Wawasan Islam pokok-pokok Pikiran Nama Islam dan Umumnya, Jakarta: Raja Grafindo Persada, 1993
Selo S, Social Changes in Yogyakarta, diterjemahkan dalam Bahasa Indonesia oleh H.J Koesmanto dan Mochtar Pabotinggi, Perubahan Sosial di Yogyakarta, Yogyakarta: Gajah Mada University Press: 1991

Sulaiman, Prolog: Dari Kearifan Lokal Menuju Kerukunan Beragama, Yogyakarta: PT Arti Bumi Intaran, 2015

Woodward,Mark R., Islam Jawa Kesalehan Normatif Versus Kebatinan, Yogyakarta: LKiS, 1989

Zaenal Abidin, Yusuf, dan Ahmad Saebani, Beni, Pengantar Sistem Sosial budaya, Bandung: Pustaka Setia,

2013 